conditions: An exploratory statistical analysis. Irish J Psych Med 1992; 9: 30-36. 20. Casey P. The imperative in PTSD: Integrating biology and clinical practice. Irish J Psych Med 2004; 21: 4-5.

21. Crabbe J, Alexander DA, Klein S, Walker S, Sinclair J. Dealing with violent and aggressive patients: At what cost to nurses? Irish J Psych Med 2002; 10: 121-124 Thahy TJ. Psychological debriefing for acute trauma: A weome demise? Irish J Psych Med 2001: 18: 43-44.

23. Fear CF. Factitious post-traumatic stress disorder revisited. Irish J Psych Med 1996; 13 : $116 \cdot 118$

24. Freyne A, O'Connor A. Post traumatic stress disorder symptoms in prisoners following a cell mate's hanging. Irish J Psych Med 1992; 9: 42-44.

25. Hull AM, Doherty PM, Bowes LJ. What is the profile of post-traumatic reactions within medical literature? A survey of eight journals. Irish J Psych Med 2002; 19: 125-127.

26. McGee D, Browne I, Kenny V, McGennis A, et al. Unexperienced experience: A critical reappraisal of the theory of repression and traumatic neurosis. Irish Journal of Psychotherapy 1984; 3: 7-19

27. McGuire B. Post-traumatic stress disorder: A review. Irish J Psychol 1990; 11: 1-23.

28. O'Neill K, Gupta K. Post-traumatic stress disorder in women who were victims of childhood sexual abuse. Irish J Psych Med 1991; 8: 124-127.

29. Tobin JP. Post traumatic stress disorder and the adrenal gland. Irish J Psych Med 2001; 18: $27 \cdot 29$

30. Tobin JP. Debriefing and post traumatic stress disorder. Irish J Psych Med 2002; 19: 35-36. 31. Walsh D, Lewis E. Debriefing and post traumatic stress disorder. Irish J Psych Med 2002; 19: 71

32. Watson IP. "Is violence a contagious disease?" The social implications of post-traumatic stress disorder. Irish J Psych Med 1990; 7: 47-52.

33. Humphries CL, Carr A. The short term effectiveness of Critical Incident Stress Debriefing Irish J Psychol 2001; 22: 188-197.

\section{The psychological health of clergy in Ireland - who cares for the carers?}

According to recent surveys among adults in Ireland, 96\% believe in God and 73\% attend church regularly. ${ }^{1}$ The Roman Catholic population in Ireland is $4,056,030$, with 1,368 parishes and 2,643 churches served by about 4,281 priests. In addition there are 17,361 men and women in various religious orders of priests, brothers and nuns. ${ }^{2.3}$ However, what is unclear is how many of these religious are suffering from work-related ill-health. The work-related health of the clergy should be a matter of not only personal, but also professional concern for mental health professionals in Ireland, as it is elsewhere ${ }^{4}$ and of course the Catholic Church, for two very practical reasons. First, work-related stress is a major factor in shaping general personal physical and mental health, and those who suffer from work-related stress may, as a consequence, fall ill in other ways. Second, work-related stress is a major factor in how well the pastoral and administrative job is done, and those who suffer from poor work-related health may consequently be ineffective in their job.

At present there have been no empirical studies to examine this issue in Ireland, unlike the UK, for instance. For example, Francis ${ }^{5}$ provided a comparison between levels of burnout, as measured by a modified version of the Maslach Burnout Inventory, ${ }^{6}$ among 1,476 Anglican clergymen ${ }^{6}$ and 1,468 Catholic priests ${ }^{7}$ in England and Wales. A synopsis of these findings is presented in the Table above.

The data shows that significant numbers of Anglican clergy and Catholic priests in England and Wales are experiencing psychological ill-health as a direct result of their work. It is also clear that Catholic priests experience higher levels of emotional exhaustion and depersonalisation than the Anglican clergy.

The question that arises from such findings is whether comparable levels of psychological health would be found among Irish Catholic priests if they were surveyed. Such applied research would serve much more than academic curiosity. First, the data could allow for both an examination

\begin{tabular}{|c|c|c|}
\hline Work-related health measures & Anglican & Catholic \\
\hline Emotional Exhaustion & $\%$ & $\%$ \\
\hline Feel working with others is a strain for them & 12 & 27 \\
\hline Feel burnt out & 8 & 14 \\
\hline Wake up feeling fatigued at the beginning of the day & 9 & 16 \\
\hline \multicolumn{3}{|l|}{ Depersonalisation } \\
\hline Less patient with parishioners than they used to be & 11 & 27 \\
\hline Feel parishioners blame clergy for their own problems & s 16 & 31 \\
\hline Don't really care what happens to some parishioners & 5 & 11 \\
\hline
\end{tabular}

of the general levels of work-related health among Irish Catholic priests, and these could be subsequently compared with samples of other occupational groups in Ireland, as well as samples of clergy from other countries, in order to assess if Irish clergy in general terms are a group at risk. Second, the data could be employed to help identify potential candidates for psychological burnout in order to implement preventative strategies. ${ }^{8}$ Burnout, or people exhaustion, has been implicated in increased sick leave, leaving, early retirement and even suicide. ${ }^{9,10}$

In the light of decreasing numbers of ordinands in training in Ireland ${ }^{2,3}$ there is a need for an overall strategy for clergy support, thus making the job more appealing to those with a vocation for the priesthood. However, a first step is an evaluation of the extent of the problem. For those concerned, and those charged with the psychological well-being of all members of our society, a nationwide survey of the workrelated health of Irish clergy warrants serious consideration.

${ }^{*}$ Christopher Alan Lewis, Senior Lecturer in Psychology, School of Psychology, University of Ulster at Magee College, BT48 7JL, Northern Ireland

Leslie J Francis, Professor of Practical Theology, University of Wales, Bangor, Gwynedd, Wales

Douglas W Turton, Research Associate, Welsh National Centre for Religious Education, University of Wales, Bangor, Gwynedd, Wales

Sharon Mary Cruise, Research Associate, School of Psychology, University of Ulster at Magee College, BT48

$7 \mathrm{JL}$, Northern Ireland. *Address correspondence

References

1. International Social Survey Program (ISSP). INTERNATIONAL SOCIAL SURVEY PROGRAM: RELIGION II, 1998 [Computer file]. Koeln, Germany: Zentralarchiv fuer Empirische Sozialforschung [producer], 2000. ICPSR version. Koeln, Germany: Zentralarchiv fuer Empirische Sozialforschung/Ann Arbor, MI: Inter-university Consortium for Political and Social Research [distributorsl, 2001.

2. The Irish Catholic Directory. Dublin: Veritas Publications, 2004.

3. Breen MJ. A fire in the forest: Religious life in Ireland. Dublin: Veritas Publications, 2001. 4. Weaver AJ, Flannelly KJ, Larson DB, Stapleton CL, Koenig HG. Mental health issues among clergy and other religious professionals: A review of research. J Pastoral Care Counsel. 2002; 56: 393-403.

5. Francis LJ. Ministry burnout: Myth or reality? Ministry Today 2005; 34: 6-12.

6. Rutledge CFJ, Francis $\amalg$. Burnout among male Anglican parochial clergy in England: Testing a modified form of the Maslach Burnout Inventory. Research in the Social Scientific Study of Religion 2004; 15: 71-93.

7. Francis LJ, Louden SH, Rutledge CFJ. Burnout among Roman Catholic parochial clergy in England and Wales: Myth or reality? Review of Religious Research 2004; 46: 5-19.

8. Francis LJ. Turton DW. Recognising and understanding burnout among the clergy: A 8. Francis $L J$, Turton DW. Recognising and understanding burnout among the clergy: $A$
perspective from empirical theology in D Herl \& ML Berman (eds), Building Bridges Over perspective from empirical theology in D Herl \& ML Berman (eds), Building Bridges Over Troubled Waters: Enhancing pastoral care and guidance. Ohio: Wyndh

10. Schaufeli WB, Maslach C, Marek T. Professional Burnout: Recent developments in theory and research. Washington, DC: Taylor and Francis, 1993. 


\section{When sleep matters in depression}

Zispin SolTab $15 \mathrm{mg}, 30 \mathrm{mg}, 45 \mathrm{mg}$ - Zispin $30 \mathrm{mg}$ Tablets (See SPCs before Prescribing)

Presentation: Zispin SolTab $15 \mathrm{mg}, 30 \mathrm{mg}, 45 \mathrm{mg}$. Peel-to-open strips of 6 orodispersible tablets each containing 15,30 or $45 \mathrm{mg}$ of mirtazapine, available in packs of 30 tablets. Zispin tablets: Blister strips of 7 tablets each containing $30 \mathrm{mg}$ of mirtazapine, available in packs of 28 tablets. Uses: Episode of major depression Administration: Zispin SolTab should be taken out of the strip with dry hands and should be placed on the tongue. The SolTab will rapidly disintegrate and can be swallowed with or without water. Zispin tablets should be taken orally, if necessary with fluid, and swallowed without chewing. Dosage: Adults and elderly: The effective daily dose is usually between 15 and $45 \mathrm{mg}$. Treatment should begin with $15 \mathrm{mg}$ daily and dosage should be reviewed and adjusted if necessary within 2 to 4 weeks of initiation of therapy. Children: Do not use in children or adolescents under 18 years. The clearance of mirtazapine may be decreased in patients with renal or hepatic insufficiency. Zispin is suitable for once-a-day administration, preferably as a single night-time dose. Treatment should be continued until the patient has been completely symptom-free for 4-6 months. Contraindications: Hypersensitivity to mirtazapine or any ingredients of Zispin. Precautions and warnings: Reversible bone marrow suppression presenting as agranulocytosis and granulocytopenia have been reported with most

antidepressants. Reversible agranulocytosis has been reported as a rare occurrence with Zispin. The physician should be alert p-vmptoms such as fever, sore throat, stomatitis or other

bf infection; if these occur, treatment should be stopped arolood counts taken. Patients should also be advised

of the importance of these symptoms. Careful dosing as well as regular and close monitoring is necessary in patients with: epilepsy and organic brain syndrome (See SPC); hepatic or renal insufficiency; cardiac diseases; low blood pressure. As with other antidepressants care should be taken in patients with: micturition disturbances like prostate hypertrophy, acute narrow-angle glaucoma and increased intra-ocular pressure. and diabetes mellitus. Treatment should be discontinued if jaundice occurs. Moreover, as with other antidepressants, the following should be taken into account: worsening of psychotic symptoms can occur when antidepressants are administered to patients with schizophrenia or other psychotic disturbances; when the depressive phase of manic-depressive psychosis is being treated, it can transform into the manic phase. As for all therapies for depression, risk of suicide, suicidal thoughts and self harm may increase in the first few weeks of treatment, see SmPC for full details. Zispin has sedative properties and may impair concentration and alertness. The use of Zispin has been associated with psychomotor restlessness. Withdrawal symptoms when treatment is discontinued are common, particularly if discontinuation is abrupt, see SmPC for full details. Interactions: Alcohol, benzodiazepines and MAO inhibitors. Pregnancy \& Lactation: Safety in human pregnancy has not been established. Use during pregnancy not recommended. Women of child bearing potential should employ an adequate method of contraception. Use in nursing parhers not recommended. Adverse reactions: The

ing adverse effects have been reported: Most common: h Lase in appetite and weight gain. Oedema. Drowsiness sedation, generally occurring during the first few weeks of treatment. (N.B. dose reduction generally does not lead to less sedation but can jeopardize antidepressant efficacy). Dizziness. Headache. Rare: (Orthostatic) hypotension. Exanthema. Mania, convulsions, tremor, myoclonus. Acute bone marrow depression (refer to SPC). Elevations in serum transaminase activities. Paraesthesia. Restless legs. Overdosage: Present experience with Zispin alone indicates that symptoms are usually mild Depression of the CNS with disorientation and prolonged sedation together with tachycardia and mild hyper- or hypotension have been reported. Treat by gastric lavage with appropriate symptomatic and supportive therapy for vital functions.

Legal Category: Prescription Medicine

Product Authorisation Numbers:

Zispin SolTab 15mg orodispersible tablet: PA 61/26/5 Price: $€ 17.03$

Zispin SolTab 30mg orodispersible tablet: PA 61/26/6. Price: $€ 34.05$

Zispin SolTab $45 \mathrm{mg}$ orodispersible tablet: PA 61/26/7 Price: $€ 51.07$

Zispin 30mg tablet: PA 261/43/2

Price: $€ 34.92$

Product Authorisation holder:

Zispin SolTab $15 \mathrm{mg}$. $30 \mathrm{mg}$ and $45 \mathrm{mg}$ orodispersible tablet: Organon Ireland Limited, P.O. Box 2857, Drynam Road, Swords. Co. Dublin, Ireland

Zispin 30mg tablet: Organon Laboratories Limited, Cambridge Science Park, Milton Road, Cambridge, CB4 OFL, UK.

Distributed by: Organon Laboratories, c/o United Drug House, Magna Drive, Magna Business Park, Citywest Road, Dublin 24, Irelaind. December 2005

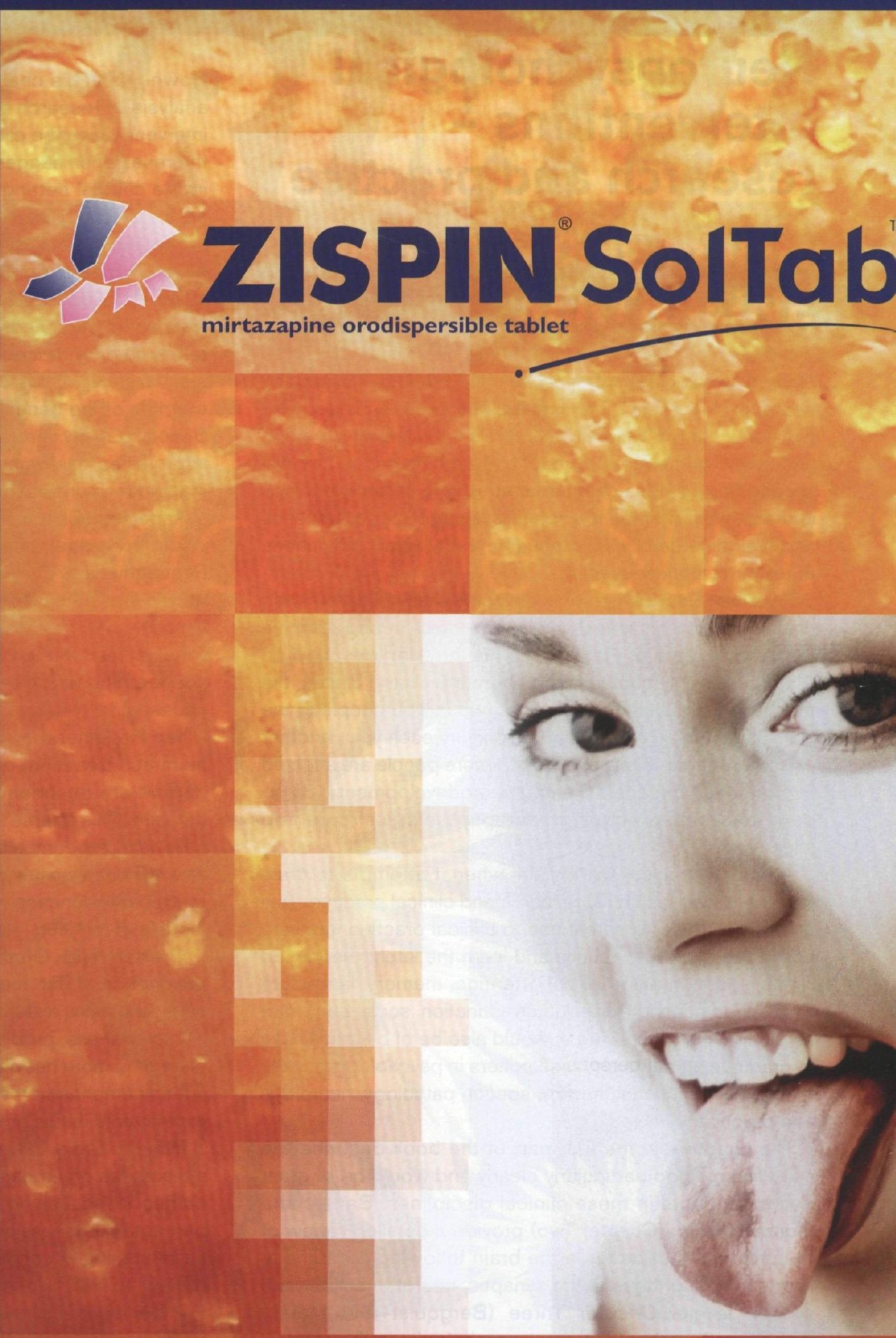

\section{The melt-in-the-mouth antidepressant with the} orange taste 